University of Nebraska - Lincoln

DigitalCommons@University of Nebraska - Lincoln

Educational Psychology Papers and

Publications

Educational Psychology, Department of

November 2005

\title{
Consultation: Conjoint Behavioral
}

John W. Eagle

University of Nebraska-Lincoln

Susan M. Sheridan

University of Nebraska-Lincoln, ssheridan2@unl.edu

Follow this and additional works at: https://digitalcommons.unl.edu/edpsychpapers

Part of the Educational Psychology Commons

Eagle, John W. and Sheridan, Susan M., "Consultation: Conjoint Behavioral" (2005). Educational Psychology Papers and Publications. 31.

https://digitalcommons.unl.edu/edpsychpapers/31

This Article is brought to you for free and open access by the Educational Psychology, Department of at DigitalCommons@University of Nebraska - Lincoln. It has been accepted for inclusion in Educational Psychology Papers and Publications by an authorized administrator of DigitalCommons@University of Nebraska - Lincoln. 
Published in Encyclopedia of School Psychology, edited by Steven W. Lee, Sage Publications, Thousand Oaks, CA, 2005, pp. 112-113. Copyright (c) 2005 Sage Publications, Inc. Used by permission.

\section{CONSULTATION: CONJOINT BEHAVIORAL}

Conjoint behavioral consultation (CBC) is defined as a "structured, indirect form of service delivery in which parents and teachers are joined together to address the academic, social, or behavioral needs of an individual" (Sheridan \& Kratochwill, 1992, p. 122). CBC incorporates a data-based, behavioral approach to supporting children's needs in naturalistic settings within an ecological-systems theoretical framework. CBC is a process that is guided by a consultant (e.g., school psychologist, special educator, or other team member) who facilitates a problem-solving process through the use of technical and interpersonal skills (Christenson \& Sheridan, 2001). The foci of CBC are remediating and preventing problems and developing home-school partnerships.

There are several differences and similarities between CBC and other forms of consultation. CBC uses the problem-solving model of behavioral consultation (Sheridan \& colleagues, 1996), which consists of four stages: problem identification, problem analysis, treatment implementation, and treatment evaluation. Similar to ecobehavioral consultation, CBC is founded upon an ecological-systems perspective that stresses the importance of the entire system surrounding a child, as well as interactions within the system. However, unlike behavioral and ecobehavioral consultation, CBC endorses conjoint (parent and teacher together), not parallel (i.e., parent-only or teacheronly) forms of interaction. In a collaborative fashion, a consultant, parents, and .teachers participate in all aspects of the CBC problem-solving process.

CBC can be used as a service delivery model for a variety of concerns. However, it appears to be most beneficial when used to address concerns that exist both at home and at school. First, CBC provides services to parents and teachers simultaneously. Second, information is gathered and expertise is shared across primary caregivers in different settings. Thus, the knowledge and perspectives of parents and teachers can be exchanged across systems. Third, CBC uses ecological assessment and intervention to increase the generalization and maintenance of treatment gains across home and school contexts. By developing consistent intervention procedures across settings, the child is more likely to receive consistent feedback and assistance in developing appropriate skills. Fourth, CBC emphasizes the establishment of a home-school partnership, in which families and schools have a shared responsibility throughout all phases of the consultation process. Thus, parents and teachers are more likely to continue to work collaboratively on immediate and future concerns.

There is an extensive and growing body of empirical research that has demonstrated the effectiveness of CBC. A large-scale study (Sheridan \& colleagues, 2001) found CBC to be an acceptable and effective mode of treatment for children's academic, social, and behavioral difficulties in naturalistic environments. This four-year longitudinal study reported positive, moderate-to-large effect sizes across home and school settings. Additionally, experimental small n-studies (e.g., studies done with one or few subjects) and case studies demonstrate that CBC is successful in treating children with irrational fears, increasing social initiation behaviors of socially withdrawn children, increasing positive social interactions of children with attention deficit hyperactivity disorder (ADHD), and improving academic performance. Finally, CBC has been found to be a more acceptable model than teacher-only consultation (Freer \& Watson, 1999).

\section{—John W. Eagle and Susan M. Sheridan}

See also Consultation: Behavioral; Consultation: Ecobehavioral; Parenting

\section{References and Further Reading}

Christenson, S. L., \& Sheridan, S. M. (2001). Schools and families: Creating essential connections/or learning. New York: Guilford.

Freer, P., \& Watson, T. S. (1999). A comparison of parent and teacher acceptability ratings of behavior and conjoint behavioral consultation. School Psychology Review, 28, 672-684.

Sheridan, S. M., Eagle, J. W., Cowan, R. J., \& Mickelson, W. (2001). The effects of conjoint behavioral consultation:

Results of a 4-year investigation. Journal of School Psychology, 39, 361-385.

Sheridan, S. M., Kratochwill, T. R., \& Bergan, J. R. (1996). Conjoint behavioral consultation: A procedural manual. New York: Plenum.

Sheridan, S. M., \& Kratochwill, T. R. (1992). Behavioral parent-teacher consultation: Conceptual and research considerations. Journal of School Psychology, 30, 117-139. 